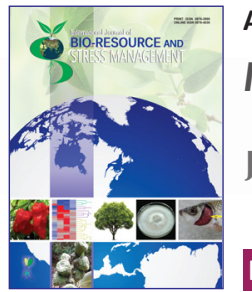

\title{
Birth Rate and Birth Weight of Crossbred Calves in Andaman and Nicobar Islands
}

\author{
P. Perumal* , A. K. De, D. Bhattacharya, A. Kundu, Jai Sunder, S. K. Ravi, P. A. Bala, \\ R. R. Alyethodi and S. K. Zamir Ahmed
}

ICAR-Central Island Agricultural Research Institute, Port Blair, Andaman and Nicobar Islands (744 101), India

G

Open Access

\section{Corresponding Author}

P. Perumal

e-mail: perumalponraj@gmail.com

Citation: Perumal et al., 2019. Birth Rate and Birth Weight of Crossbred Calves in Andaman and Nicobar Islands. International Journal of Bio-resource and Stress Management 2019, 10(3):323-328. HTTPS:// DOI.ORG/10.23910/IJBSM/2019.10.3.2000

Copyright: @ 2019 Perumal et al. This is an open access article that permits unrestricted use, distribution and reproduction in any medium after the author(s) and source are credited.

Data Availability Statement: Legal restrictions are imposed on the public sharing of raw data. However, authors have full right to transfer or share the data in raw form upon request subject to either meeting the conditions of the original consents and the original research study. Further, access of data needs to meet whether the user complies with the ethical and legal obligations as data controllers to allow for secondary use of the data outside of the original study.

Conflict of interests: The authors have declared that no conflict of interest exists.

Acknowledgement: This article is totally bases on available records or data in Animal Science Division, ICAR-Central Island Agricultural Research Institute, Port Blair, Andaman and Nicobar Islands. All authors recognize and acknowledge the Director, Head and Staff of Animal Science Division for their efforts.

\begin{abstract}
Effect of month, season and year on calving pattern and birth weight of calves in crossbred dairy cows reared under semi-intensive organised farm in Andaman and Nicobar Islands, India was analysed. The birth rate and birth weight data of 207 calves born during 1999 to 2016 at Livestock Farm Complex, ICAR-Central Island Agricultural Research Institute (ICAR-CIARI), Andaman and Nicobar Islands, India was analysed. Calving rate (\%) and birth weight of calves $(\mathrm{kg})$ under different months (January to December), seasons (wet and dry seasons) and years (1999 to 2016) were calculated. Relative female ratio (RFR) and secondary sex ratio (SSR) were also calculated to assess the sex ratio of the calves in dairy farm. Result revealed highest birth rate in the months of April, August and May, intermediate in January, February, and October to December and lowest in March, June, July and September. Birth-rate (year-wise) showed a non-cyclical fluctuation throughout the period of data analysis. Birth weight was non-significantly $(p=0.05)$ differed between sexes, among seasons, months and years. Birth weight was non-significantly ( $p=0.05$ ) higher in male than in female and in wet than in dry season. Maximum calving was during wet season. In conclusion, sex ratio and birth weight were not differed among the months or among years or between seasons. However, wet season/months were found to be most conducive for breeding of crossbred cattle under semi-intensive system in Andaman and Nicobar Islands, India.
\end{abstract}

Keywords: Andaman Islands, birth weight, calving pattern, cattle, season

\section{Introduction}

The sex ratio of new born animals is an important factor of any dairy herd in replacing low performing animals, maintaining proper herd strength and achieving sustainable production/reproduction rate leading to increased profitability of farming (Dhakal et al., 2013). As per the Ministry of Agriculture, Government of India, per capita availability of milk is 110 $\mathrm{g} \mathrm{day}^{-1}$ and $337 \mathrm{~g} \mathrm{day}^{-1}$ and milk production is 15000 tonnes and 155.5 million tonnes in Andaman \& Nicobar Islands and India, respectively $\left(19^{\text {th }}\right.$ Livestock Census of India, 2012) whereas per capita requirement of milk as per Indian Council of Medical Research (ICMR) is $230 \mathrm{~g}$. In this context, it is required to increase the milk production and per capita availability in the Island. Vision 2050 of ICAR-CIARI on milk production indicated that milk deficit was $44 \%$ in 2011 and it will be increased in 2050 in A \& N Islands. Milk production and per capita availability have decreased over a period of time from 2001 to 2016 in these islands. The
Article History

RECEIVED in $24^{\text {th }}$ May 2019 RECEIVED in revised form $26^{\text {th }}$ June 2019 ACCEPTED in final form form $30^{\text {th }}$ June 2019 
population of milk producing dairy cows has decreased from 1992 to 2012 whereas the human population has increased drastically in A \& N Islands. As per the $19^{\text {th }}$ Livestock Census of India (2012), cattle in milk were 9388 and in non-milk were 8530 , in case of buffalo; it was 1100 and 1237, respectively in Andaman and Nicobar Islands. Cattle were not in milk are due to sterile or infertile cattle or suffered from different reproductive disorders. Therefore, it is strongly required to increase the female calf ratio to select elite female calf as the future progeny for higher milk production in Andaman and Nicobar Islands to increase milk production and increase the per capita availability of milk (Perumal et al., 2018). Calving rate in dairy farm depends on climate, housing system, nutritional status, incidence of diseases, calving to conception interval and many other managemental practices (López et al., 2018). Although the sex of a calf is determined at fertilization, preferential embryo/foetal mortality may also impact the secondary sex ratio (Glover et al., 2019). Therefore, it is likely that the factors acting at fertilization or early in gestation play a large role in sex determination (Schmidek et al., 2013). Andaman and Nicobar islands are tropical hot humid with the average ambient temperature ranging between 23-30 ${ }^{\circ} \mathrm{C}$ and relative humidity in the range of $82-94 \%$. The annual rainfall is more than $3100 \mathrm{~mm}$ spread over 8 months and 4 months of dry season in a year. Factors such as season and year are the effective factors to determine the sex ratio and calving rate (Perumal et al., 2014; Singh et al., 2004; Kaygisiz and Vanli, 2008). Further, perusal of literatures revealed no information available on the effect of season, month and year on sex ratio and birth weight under semi-intensive system of dairy farm in Andaman \& Nicobar Islands or island ecosystem in India. However, similar type of works were reported earlier in other domestic animal species in other places of experiment (Mukherjee et al., 2000; Biradar and Suranagi, 2003; Kaygisiz et al., 2003; Singh et al., 2004; Lari, 2006; Roche et al., 2006; Farahvash et al., 2008; Perumal et al., 2014). Therefore, the data was analysed retrospectively to assess the effect of month, season and year on calving pattern and birth weight of crossbred dairy calves reared under semi-intensive system in Andaman and Nicobar Islands.

\section{Materials and Methods}

\subsection{Location of the study}

The data was collected from Livestock Farm Complex, Division of Animal Science, ICAR-Central Island Agricultural Research Institute, Port Blair, Andaman and Nicobar Islands, India and analysed. The centre is located between $6045^{\prime}$ to $13^{\circ} 41^{\prime}$ North Latitude and $92^{\circ} 12^{\prime}$ to $93^{\circ} 57^{\prime}$ East Longitude.

\subsection{Climate}

Average maximum temperature is $30.1{ }^{\circ} \mathrm{C}$ and minimum temperature is $23{ }^{\circ} \mathrm{C}$. Relative humidity is in the range of $82-94 \%$. The annual rainfall is more than $3100 \mathrm{~mm}$ spread over 8 months and remaining 4 months as dry season in a year in the experimental station.

\subsection{Management of animals}

Jersey and Holstein Friesian crossbred cattle ( $n=55$; crossbred with local non-descriptive cattle) were maintained in the semi-intensive system with sex ratio of 1: 10 (50 cows and 5 bull). Jersey crossbred (cow: 30, bull: 3) and Holstein Friesian crossbred (cow: 20 and bull: 2) cattle were maintained separately. The blood level was maintained at $60-70 \%$ of exotic germplasm in the crossbred cows. The crossbred cattle were maintained in the well ventilated house and under proper hygiene. These crossbred cattle were vaccinated, dewormed and other prophylactic measures undertaken properly as per the farm schedule. The animal house was made up of asbestos-roof, half of the wall made up of wire mesh and half was by the bricks wall in all four side of the shed. Moreover, the animal shed was surrounded by trees. The animals were allowed for grazing from 0800 to 1300 hours and then the animals were tied in the shed. These animals were fed and watered individually using separate feeding and watering troughs in the afternoon after returning back from grazing as per the farm schedule. Ad libitum clean drinking water was available all the time. Adult animals were offered $25 \mathrm{~kg}$ chopped green forage contains $19.10 \%$ dry matter and $10.30 \%$ crude protein and $5 \mathrm{~kg}$ concentrates contains $86.50 \%$ dry matter and $13.20 \%$ crude protein potentiated with mineral mixture and salt. Bull parading was implemented every day in the morning and in the evening to find out the estrus animal. Estrus was identified by different behavioural and physical signs. The estrus animals were allowed to be mounted upon and copulate with suitable male of same breed as natural breeding practices in a separate place. In the present dairy farm, the sex ratio of 1:10 is allowed for breeding purpose.

\subsection{Data recording}

The data related to sex of calves, calving year, season and month from the year 1999 to 2016 were collected, grouped and analysed for the study. Calving season was classified as wet season (April to November) and dry season (December to March) based on the monsoon. Secondary sex ratio (SSR) has been calculated as per the procedure followed by Mora et al. (2010) which has been described as under. SSR= $(A / C) \times 100$ : $(B / C) \times 100$; Where, $A=$ the number of male calves, $B=$ the number of female calves and $C=$ the number of total calves $(A+B)$.

Relative Female Ratio (RFR) was calculated from number of female and male calves for dairy cattle. Numbers of male and female calves become equal to each other when $R F R=1$. Number of female calves is more than that of male when RFR $>1$. Number of male calves is more than that of female when RFR $<1$ (Yilmaz et al., 2010).

\subsection{Statistical analysis}

The data were analysed statistically with the standard protocols. Analysis of variance was done with a generalized liner model (SPSS, version, 16, Chicago, IL, USA) and using Student-Newman-Kuels (SNK) multiple range test. The data 
used in the study were tested for normality before analysis using Shapiro Wilk statistics. One way ANOVA was used to measure the variation among the months, years for different sex. Student " $t$ " test was done to study the variation between the male and female in different months, seasons and years. Differences with values of $p<0.05$ were considered to be statistically significant.

\section{Results and Discussion}

Calf sex varied between the months. The proportion of female and male calves born in farm was 50.25: 49.75. Overall RFR and SSR values were 1.00 and 1:1.01, respectively. The RFR was $>1$ in February, March, June, August and October. In July, it was 1.00 and in other months, it was $<1$ (Table 1). Broadly,

Table 1: Month-wise calving and sex ratio of crossbred calves reared under semi-intensive system in Andaman \& Nicobar Islands

\begin{tabular}{|c|c|c|c|c|c|}
\hline \multirow[t]{2}{*}{ Month } & \multicolumn{2}{|c|}{$\begin{array}{c}\text { Sex-wise } \\
\text { frequency (\%) }\end{array}$} & \multirow[t]{2}{*}{$\begin{array}{l}\text { Total calf } \\
\text { crop (\%) }\end{array}$} & \multirow[t]{2}{*}{ RFR } & \multirow[t]{2}{*}{ SSR } \\
\hline & Male & Female & & & \\
\hline Jan & $\begin{array}{c}10 \\
(71.42)\end{array}$ & $\begin{array}{c}4 \\
(28.58)\end{array}$ & $14(6.76)$ & 0.40 & $1: 0.40$ \\
\hline Feb & $\begin{array}{c}7 \\
(46.66)\end{array}$ & $\begin{array}{c}8 \\
(53.34)\end{array}$ & $15(7.24)$ & 1.14 & 1:1.14 \\
\hline March & $\begin{array}{c}4 \\
(33.33)\end{array}$ & $\begin{array}{c}8 \\
(66.67)\end{array}$ & $12(5.79)$ & 2.00 & $1: 2.00$ \\
\hline April & $\begin{array}{c}15 \\
(51.72)\end{array}$ & $\begin{array}{c}14 \\
(48.28)\end{array}$ & $\begin{array}{c}29 \\
(14.00)\end{array}$ & 0.93 & 1:0.93 \\
\hline May & $\begin{array}{c}16 \\
(59.25)\end{array}$ & $\begin{array}{c}11 \\
(40.75)\end{array}$ & $\begin{array}{c}27 \\
(13.04)\end{array}$ & 0.68 & $1: 0.68$ \\
\hline June & $\begin{array}{c}1 \\
(11.11)\end{array}$ & $\begin{array}{c}8 \\
(88.89)\end{array}$ & $9(4.34)$ & 8.00 & $1: 8.00$ \\
\hline July & $\begin{array}{c}4 \\
(50.00)\end{array}$ & $\begin{array}{c}4 \\
(50.00)\end{array}$ & $8(3.86)$ & 1.00 & 1.1 .00 \\
\hline August & $\begin{array}{c}13 \\
(46.42)\end{array}$ & $\begin{array}{c}15 \\
(53.58)\end{array}$ & $\begin{array}{c}28 \\
(13.52)\end{array}$ & 1.15 & $1: 1.15$ \\
\hline September & $\begin{array}{c}7 \\
(58.33)\end{array}$ & $\begin{array}{c}5 \\
(41.67)\end{array}$ & $12(5.79)$ & 0.71 & 1:0.71 \\
\hline October & $\begin{array}{c}8 \\
(40.00)\end{array}$ & $\begin{array}{c}12 \\
(60.00)\end{array}$ & $20(9.66)$ & 1.50 & $1: 1.50$ \\
\hline November & $\begin{array}{c}10 \\
(55.55)\end{array}$ & $\begin{array}{c}8 \\
(44.45)\end{array}$ & 18 (8.69) & 0.80 & $1: 0.80$ \\
\hline December & $\begin{array}{c}9 \\
(60.00)\end{array}$ & $\begin{array}{c}6 \\
(40.00)\end{array}$ & $15(7.24)$ & 0.66 & 1:0.66 \\
\hline Average & $\begin{array}{c}103 \\
(49.75)\end{array}$ & $\begin{array}{c}104 \\
(50.25)\end{array}$ & $\begin{array}{c}207 \\
(100)\end{array}$ & 1.00 & 1.01 \\
\hline
\end{tabular}

RFR: Relative female ratio; SSR: Secondary sex ratio $(n=50)$ maximum calving rate was observed in monsoon/wet season (April to November) and lowest in dry season (December to March) (Table 2). Similarly RFR in monsoon season (April to

Table 2: Season-wise calving and sex ratio of crossbred calves reared under semi-intensive system in Andaman \& Nicobar Islands

\begin{tabular}{lccccc}
\hline Season & \multicolumn{2}{c}{$\begin{array}{c}\text { Sex-wise } \\
\text { frequency (\%) }\end{array}$} & \multirow{2}{*}{$\begin{array}{c}\text { Total calf } \\
\text { crop (\%) }\end{array}$} & RFR & SSR \\
\cline { 2 - 4 } & Male & Female & & & \\
\hline Wet & 74 & 77 & 151 & 1.04 & $1: 1.04$ \\
& $(49.01)$ & $(50.99)$ & $(72.94)$ & & \\
Dry & 30 & 26 & 56 & 0.86 & $1: 0.86$ \\
& $(53.57)$ & $(46.43)$ & $(27.06)$ & & \\
\hline
\end{tabular}

RFR: Relative female ratio; SSR: Secondary sex ratio $(n=50)$

November) was $>1$ and in dry season, it was $<1$ (Table 2 ). RFR for 2002, 2003, 2005, 2006, 2011, 2013 and 2016 was >1, for the year 2007, it was $=1$ and for other years, it was $<1$ (Table 3 ).

Table 3: Year-wise calving and sex ratio of crossbred calves reared under semi-intensive farming system in Andaman \& Nicobar Islands

\begin{tabular}{|c|c|c|c|c|c|}
\hline \multirow[t]{2}{*}{ Year } & \multicolumn{2}{|c|}{$\begin{array}{c}\text { Sex-wise } \\
\text { frequency (\%) }\end{array}$} & \multirow{2}{*}{$\begin{array}{c}\text { Total } \\
\text { calf crop } \\
(\%)\end{array}$} & \multirow[t]{2}{*}{ RFR } & \multirow[t]{2}{*}{ SSR } \\
\hline & Male & Female & & & \\
\hline 1999 & $3(75.00)$ & $1(25.00)$ & 4 (1.93) & 0.33 & \\
\hline 2000 & $6(60.00)$ & $4(40.00)$ & $10(4.83)$ & 0.66 & $1: 0.66$ \\
\hline 2001 & $8(80.00)$ & $2(20.00)$ & $10(4.83)$ & 0.25 & $1: 0.25$ \\
\hline 2002 & $5(45.45)$ & $6(54.55)$ & $11(5.31)$ & 1.20 & $1: 1.20$ \\
\hline 2003 & $4(33.33)$ & $8(66.67)$ & $12(5.80)$ & 2.00 & 1:2.00' \\
\hline 2004 & $10(66.66)$ & $5(33.34)$ & $15(7.25)$ & 0.50 & $1: 0.50$ \\
\hline 2005 & $5(38.46)$ & $8(61.54)$ & $13(6.28)$ & 1.60 & $1: 1.60$ \\
\hline 2006 & 2 (15.38) & 11 (84.62) & $13(6.28)$ & 5.50 & $1: 5.50$ \\
\hline 2007 & $4(50.00)$ & $4(50.00)$ & $8(3.86)$ & 1.00 & $1: 1.00$ \\
\hline 2008 & $6(66.66)$ & $3(33.34)$ & $9(4.35)$ & 0.50 & $1: 0.50$ \\
\hline 2009 & 9 (64.28) & 5 (35.72) & $14(6.76)$ & 0.55 & $1: 0.55$ \\
\hline 2010 & $10(55.55)$ & $8(44.45)$ & $18(8.70)$ & 0.80 & $1: 0.80$ \\
\hline 2011 & 5 (38.46) & 8 (61.54) & $13(6.28)$ & 1.60 & $1: 1.60$ \\
\hline 2012 & $8(57.14)$ & $6(42.86)$ & $14(6.76)$ & 0.75 & $1: 0.75$ \\
\hline 2013 & $3(42.85)$ & $4(57.15)$ & 7 (3.38) & 1.33 & $1: 1.33$ \\
\hline 2014 & $6(54.54)$ & $5(45.46)$ & $11(5.31)$ & 0.83 & $1: 0.83$ \\
\hline 2015 & $8(66.66)$ & $4(33.34)$ & $12(5.80)$ & 0.50 & $1: 0.50$ \\
\hline 2016 & $2(16.66)$ & $10(83.34)$ & $12(5.80)$ & 5.00 & $1: 5.00$ \\
\hline $\begin{array}{l}\text { Aver- } \\
\text { age }\end{array}$ & $103(49.75)$ & $104(50.25)$ & $\begin{array}{c}207 \\
(100.00)\end{array}$ & 1.00 & $1: 1.01$ \\
\hline
\end{tabular}

RFR: Relative female ratio, SSR: Secondary sex ratio $(n=50)$ 
Results of RFR indicated that there was a non-cyclical fluctuation in male and female calf ratio \& total number of the calf borne and in overall; it was 50:50 or 1:1. The SSR of $50 \%$ males reported in the present study disagreed with earlier studies in dairy cattle which showed higher incidence of males than females (Xu et al., 2000; Roche et al., 2006). The results showed that between the calving year and sex and between calving month \& sex revealed non-significant association. Similar result was reported by Kaygisiz et al. (2003) in Holstein cattle, Mukherjee et al. (2000) in Karan Swiss cows indicated that there was no significant difference between the calving year and sex. It was also observed that calving year did not influence on RFR and SSR in Deoni cows (Biradar and Suranagi, 2003) and Jersey $\times$ Sindhi crossbred cows (Biradar, 1996). Farahvash et al. (2008) reported that the RFR value was $>1$ (RFR $>1.00)$ in Holstein or its crossbred herds in East Azarbijan. The RFR and SSR are varied from year to year and also depended upon the year (Farahvash et al., 2008). The relationship between the calving season and sex was significant and more male calf was obtained in dry season and more female calf was obtained in monsoon season. The main factor affected the sex ratio of the calf was type of breeding, either artificial insemination or natural service, which in the present study indicated that the sex ratio was decreased and this was reflected in the present study (Kul et al., 2018). One contributing factor to the annual effect on sex ratio is may be climate and its associated effects on sex ratio (Roche et al., 2006). Skjervold and James (1978) reported a significant effect of calving season on sex ratio in dairy cattle. Lari (2006), Roche et al. (2006) and Singh et al. (2004) reported that the calving season did not affect the sex ratio, RFR and SSR in different cattle breeds. There are various factors such as sire, age of sire, parity, calving year, calving season, climate, insemination time and maternal factors (age, stress etc.) affect the secondary sex ratio and RFR at birth in dairy cattle (Motus et al., 2018). Roche et al. (2006) reported a significant effect of climate at conception and indicators of cow metabolic load (i.e. body condition score) at conception on secondary sex ratio. Climate in Andaman \& Nicobar Islands follows a clear demarked seasonal pattern as dry and monsoon, thus, providing one possible explanation for the effect of season/ time of year on sex ratio in the Island (Damiran et al., 2018). The relative humidity is highest in the month of August and lowest in February. The climatic conditions are warm, rainy and humid in Andaman and Nicobar Islands. Some soils are deficient in micro nutrients. Though, annual rainfall is 3100 $\mathrm{mm}$, it is intense during rainy season and virtual drought during the dry period was also observed. Xu et al. (2000) reported a heritability of sex ratio of $2 \%$ suggesting that the permanent environmental effect of the dam is the main contributor to the repeatability of sex ratio. Though, it is said that dairy cattle is bred throughout the year and no definite breeding season is observed as the perennial breeder and poly estrus animal but the trend of calving at dairy farm, Andaman \& Nicobar Islands compel us to speculate about some sort of seasonality to exist in dairy cattle in the Islands. , Breeding takes place in forest itself in semi-intensive dairy farm. Dairy farm records indicated that maximum calving took place in the month of April, May and August, which means, most of the breeding might have taken place in the month of July, August and November. Similarly lowest calving was recorded during the month of September and October, which means, very less number of animal had been in estrus in month of September and October considering the gestation length of 290 days. The nutritional problem becomes more acute during dry season, where there was very less grass to feed upon. Further, it could be contemplated that temperature and humidity might be affecting the sexual desire of the animals. Comparatively less number of animals breeds during the month of heavy rain fall as because, only few animals are exhibit the estrus behaviour (Nascimento et al., 2019). Maximum number of animal bred in July, August and November. Birth rate in year wise showed a non-cyclical fluctuation throughout the experimental period. Birth weight showed non-significant difference between months (Table 4), sexes and seasons (Table 5 ) and years (Table 6 ) in the present study. Non-significantly higher weight was observed in male than in female and in wet than in dry season.

Table 4: Month-wise mean birth weight (kg士S.E) of crossbred calves reared under semi-intensive system in Andaman \& Nicobar Islands

\begin{tabular}{lccc}
\hline Month & Male & Female & Average \\
\hline January & $19.73 \pm 0.64$ & $23.25 \pm 0.50$ & $21.49 \pm 0.55$ \\
February & $22.91 \pm 0.29$ & $19.93 \pm 0.25$ & $21.42 \pm 0.52$ \\
March & $22.25 \pm 1.21$ & $20.06 \pm 0.77$ & $21.16 \pm 0.65$ \\
April & $22.40 \pm 0.61$ & $21.79 \pm 0.61$ & $22.09 \pm 0.43$ \\
May & $23.89 \pm 0.56$ & $22.35 \pm 0.61$ & $23.12 \pm 0.41$ \\
June & $20.32 \pm 0.64$ & $19.49 \pm 0.68$ & $19.90 \pm 0.63$ \\
July & $22.00 \pm 1.18$ & $18.63 \pm 0.52$ & $20.31 \pm 0.72$ \\
August & $21.69 \pm 0.55$ & $20.87 \pm 0.49$ & $21.28 \pm 0.36$ \\
September & $23.29 \pm 0.63$ & $21.80 \pm 0.69$ & $22.54 \pm 0.46$ \\
October & $24.99 \pm 0.83$ & $22.72 \pm 0.43$ & $23.85 \pm 0.46$ \\
November & $23.14 \pm 0.81$ & $21.83 \pm 0.79$ & $22.48 \pm 0.57$ \\
December & $21.83 \pm 0.79$ & $22.17 \pm 0.97$ & $22.00 \pm 0.61$ \\
Overall & $22.52 \pm 0.22$ & $21.09 \pm 0.19$ & $21.81 \pm 0.14$ \\
\hline
\end{tabular}

Table 5: Season-wise mean birth weight $(\mathrm{kg} \pm \mathrm{S} . \mathrm{E})$ of crossbred calves reared under semi-intensive system in Andaman \& Nicobar Islands

\begin{tabular}{lccc}
\hline Season & Male & Female & Average \\
\hline Wet season & $22.96 \pm 0.26$ & $21.12 \pm 0.22$ & $22.02 \pm 0.17$ \\
Dry season & $21.44 \pm 0.40$ & $20.96 \pm 0.42$ & $22.23 \pm 0.28$ \\
Overall & $22.52 \pm 0.22$ & $21.09 \pm 0.19$ & \\
\hline
\end{tabular}


Table 6: Year-wise mean birth weight (kg士S.E) of crossbred calves reared under semi-intensive system in Andaman \& Nicobar Islands

\begin{tabular}{lccl}
\hline Year & Male & Female & Average \\
\hline 1999 & $21.33 \pm 1.22$ & $21.03 \pm 1.88$ & $21.21 \pm 0.97$ \\
2000 & $18.84 \pm 0.81$ & $27.50 \pm 1.06$ & $22.34 \pm 0.76$ \\
2001 & $21.87 \pm 0.84$ & $23.43 \pm 1.32$ & $22.21 \pm 0.72$ \\
2002 & $19.82 \pm 0.80$ & $21.51 \pm 0.61$ & $20.72 \pm 0.53$ \\
2003 & $22.75 \pm 0.97$ & $22.18 \pm 0.89$ & $22.37 \pm 0.67$ \\
2004 & $21.29 \pm 0.58$ & $19.12 \pm 0.64$ & $20.52 \pm 0.46$ \\
2005 & $20.72 \pm 1.15$ & $19.67 \pm 0.35$ & $19.38 \pm 0.63$ \\
2006 & $25.50 \pm 1.32$ & $21.90 \pm 0.62$ & $22.46 \pm 0.57$ \\
2007 & $19.00 \pm 0.70$ & $19.37 \pm 0.92$ & $19.18 \pm 0.63$ \\
2008 & $24.13 \pm 0.96$ & $21.00 \pm 1.09$ & $22.42 \pm 0.83$ \\
2009 & $23.38 \pm 0.80$ & $23.04 \pm 0.91$ & $23.26 \pm 0.62$ \\
2010 & $20.72 \pm 0.67$ & $20.67 \pm 0.70$ & $20.76 \pm 0.48$ \\
2011 & $22.22 \pm 1.21$ & $21.91 \pm 0.57$ & $22.03 \pm 0.60$ \\
2012 & $23.08 \pm 0.91$ & $22.33 \pm 0.75$ & $22.76 \pm 0.62$ \\
2013 & $21.33 \pm 0.43$ & $20.87 \pm 0.69$ & $21.15 \pm 0.57$ \\
2014 & $22.52 \pm 0.62$ & $21.90 \pm 0.62$ & $22.21 \pm 0.51$ \\
2015 & $23.04 \pm 0.69$ & $21.75 \pm 0.74$ & $22.91 \pm 0.55$ \\
2016 & $22.50 \pm 0.59$ & $21.90 \pm 0.50$ & $22.08 \pm 0.43$ \\
Average & $22.52 \pm 0.22$ & $21.09 \pm 0.19$ & $21.81 \pm 0.14$ \\
\hline
\end{tabular}

NS: Non-significant

Though, the cattle is poly-estrous animal and adult female shows repeated estrus cycle after every 19-24 days interval with silent estrous without bellowing and having standing heat period ranging from 4-16 hours in Andaman \& Nicobar Islands. The expression of estrus behaviour is silent in this crossbred and it is difficult to detect heat in female by clinical symptoms (Rai et al., 2004). Cattle entirely depend on the locally available jungle fodders for obtaining mineral elements and leaching of mineral elements is a common phenomenon during rainy season in the hilly terrain. Therefore, in a particular grazing gradient, the soil will be deficient in some important mineral elements. In that case, the vegetation of that particular area will also be deficient in some of the mineral elements, which may induce mineral deficiency (Das et al., 2011), which probably affects estrus exhibition in rainy season too.

\section{Conclusion}

Breeding has occurred throughout the year in cattle of Andaman and Nicobar Islands, however, wet season/months were found to be most conducive for cattle breeding under semi-intensive system. It warrants further investigation involving detailed study of endocrinological profiles throughout the year in a larger population under semiintensive condition to establish the breeding season and months in Andaman and Nicobar Islands.

\section{Acknowledgement}

This article is totally bases on available records or data in Animal Science Division, ICAR-Central Island Agricultural Research Institute, Port Blair, Andaman and Nicobar Islands. All authors recognize and acknowledge the Director, Head and Staff of Animal Science Division for their efforts.

\section{References}

Biradar, U.S., 1996. Sex ratio in a closed herd of Jersey $x$ Sindhi crossbred cattle. Journal of Dairying, Foods and Home Science 15(1), 69-70.

Biradar, U.S., Suranagi, M.D., 2003. Effect of seasons and periods of birth on sex ratio in Deoni cattle. Karnataka Journal of Agricultural Science 16(2), 335-336.

Damiran, D., Larson, K.A., Pearce, L.T., Erickson, N.E. Lardner, B.H.A., 2018. Effect of calving period on beef cow longevity and lifetime productivity in western Canada. Translational Animal Science 2(supple 1), S61-S65.

Das, K.C., Haque, N., Baruah, K.K., Rajkhowa, C., Mondal, M., 2011. Comparative nutrient utilization, growth, and rumen enzyme profile of mithun (Bos frontalis) and ThoTho cattle (Bos indicus) fed on tree-leaves-based ration. Tropical Animal Health Production 43(1), 209-214.

Dhakal, K., Maltecca, C., Cassady, J.P., Baloche, G., Williams, C.M., Washburn, S.P., 2013. Calf birth weight, gestation length, calving ease, and neonatal calf mortality in Holstein, Jersey, and crossbred cows in a pasture system. Journal of Dairy Science 96(1), 690-698.

Farahvash, T.S., Adabi, G., Ahmadzadeh, A., Davoodi, J., 2008. Some factors affecting sex ratio of dairy herds in East Azarbijan, Iran. Asian Journal of Animal Veterinary Advances 3(5), 357-362.

Glover, I.D., Barrett, D.C., Reyher, K.K., 2019. Little association between birth weight and health of preweaned dairy calves. Veterinary Record 184, 477.

Kaygisiz, A., Vanli, Y., 2008. Factors influencing sex ratio in Brown Swiss Cattle. Indian Journal of Animal Sciences 78(6), 656-657.

Kaygisiz, A., Vanli, Y., Cakmak, L., 2003. Estimates of genetic and phenotypic parameters of sex ratio in Holstein cattle. GAP III. Agricultural Congress, Sanliurfa, Turkiye.

Kul, E., Filik, G., Sahin, A., Cayıroglu, H., Ugurlutepe, E., Erdem, H., 2018. Effects of some environmental factors on birth weight of Anatolian buffalo calves. Turkish Journal of Agriculture-Food Science and Technology 6(4), 444-446.

Lari, M.A., 2006. Sex ratio at birth in dairy herds in Fars province, Southern Iran. Tropical Animal Health Production 38(7-8), 593-595.

Lopez, E., Veliz, F.G., Carrillo, E., Santiago, A.D., Garcia, J.E., 
Mellado, M., 2018. Effect of birth weight, weaning weight and pre-weaning weight gain on fertility of Holstein heifers under hot Mexican conditions. Slovenian Veterinary Research 55(1), 35-42.

Motus, K., Viltrop, A., Emanuelson, U., 2018. Reasons and risk factors for beef calf and youngstock on-farm mortality in extensive cow-calf herds. Animal 12(9), 1958-1966.

Nascimento, F.G.D.O., Aguiar, H.C.P., Rodrigues, G.M., Guimaraes, E.C., Nascimento, M.R.B.D.M., 2019. What is the best temperature-humidity index equation to indicate heat stress in crossbred dairy calves in a tropical environment?. Ciência Rural 49(1), e20180132.

Perumal, P., Kumar, B., Rajkhowa, C., 2014. Calving trend in mithun. Indian Journal of Animal Sciences 84(7), 750-752.

Perumal, P., Kundu, A., Kundu, M. S., Sunder, J., Bhattacharya, D., Sujatha, T., De, A.K., 2018. Reproductive and production performances in dairy cattle of bay islands under semi-intensive organized farm: a review. Journal of Cell and Tissue Research 18(1), 6375-6382.
Roche, J.R., Lee, J.M., Berry, D.P., 2006. Climatic factors and secondary sex ratio in dairy cows. Journal of Dairy Science 89, 3221-3227.

Schmidek, A., Costa, M.J.R.P.D., Mercadante, M.E.Z., Toledo, L.M.D., Cyrillo, J.N.D.S.G., Branco, R.H., 2013. Genetic and non-genetic effects on calf vigor at birth and preweaning mortality in Nellore calves. Revista Brasileira de Zootecnia 42(6), 421-427.

Singh, B., Kumar, D., Singh, H., Prasad, R.B., Singh, J.B., 2004. Genetic studies on sex ratio in dairy cattle. Indian Journal of Animal Sciences 74(9), 986-988.

Skjervold, H., James, J.W., 1978. Causes of variation in the sex ratio in dairy cattle. Zeit Tier Zuch 95, 293-305.

Xu, Z.Z., Johnson, D.L., Burton, L.J., 2000. Factors affecting the sex ratio in dairy cattle in New Zealand. Proceedings of New Zealand Society for Animal Production 60, 301-302.

Yilmaz, I., Eyduran, E., Kaygisiz, A., 2010. Determination of some environmental factors related to sex ratio of Brown Swiss calves. The Journal of Animal and Plant Science 20(3), 164-169. 